\title{
Formation of the Yukaghir National School
}

\section{Formación de la Escuela Nacional Yukaghir}

\author{
Tatyana V. Tretyakova* \\ Ammosov North-Eastern Federal University, Yakutsk, Russian Federation. \\ ORCID: http://orcid.org/0000-0002-4391-5556 \\ Vyacheslav I. Shadrin \\ Siberian Branch of the Russian Academy of Sciences, Yakutsk, Russian Federation. \\ ORCID: http://orcid.org/0000-0002-8941-4634
}

\section{Tatyana N. Petrova}

Mari State University, Yoshkar-Ola, Russian Federation.

\section{Inna V. Vorobiyova}

Yakovlev Chuvash State Pedagogical University, Cheboksary, Russian Federation.

ORCID: http://orcid.org/0000-0001-9417-6477

\section{Lyudmila E. Shadrina}

Nelemnoye secondary school named after Spridonov N.I.-Tekki Odulok, Nelemnoye village, Russian Federation.

ORCID: http://orcid.org/0000-0003-4526-6438

\section{Received 07-12-20 Revised 08-04-20 Accepted 09-13-20 On line 09-22-20}

\section{*Correspondence}

Email: t.v.tretyakova@rambler.ru
Cite as:

Tretyakova, T.V., Shadrin, V.I., Petrova, T.N., Vorobiyova, I.V., Shadrina, L.E. (2020). Formation of the Yukaghir National School. Propósitos y Representaciones, 8 (SPE3), e717. Doi: http://dx.doi.org/10.20511/pyr2020.v8nSPE3.717 


\section{Summary}

The problems of preserving the language and culture of small ethnic groups are relevant in world society. The Yukaghirs are one of the disappearing ethnic groups due to their small number and long-term adaptation in a multi-ethnic environment that does not contribute to the development and preservation of linguistic and cultural traditions. The lack of a language environment, scientifically grounded educational programs and teaching materials, violation of psychological foundations that contribute to the preservation of an ethnic group are the main bases of the relevance of the study. The article presents the results of a long-term educational experiment on the preservation of the Yukaghir language and culture in the Nelemnoye secondary school of the Verkhnekolymsky district of the Republic of Sakha (Yakutia), the successful management of the educational process in the new conditions, its progressive expansion, development, and creation of a socio-educational space to preserve the native language and culture in the Yukaghir village. The practical results of the experiment can be used to solve similar problems in the world's educational society.

Keywords: Yukaghirs; National School; Yukaghir Language; Traditional Culture; Educational Work.

\section{Resumen}

Los problemas de preservar el idioma y la cultura de los pequeños grupos étnicos son relevantes en la sociedad mundial. Los yukaghires son uno de los grupos étnicos en desaparición debido a su pequeño número y adaptación a largo plazo en un entorno multiétnico que no contribuye al desarrollo y preservación de las tradiciones linguísticas y culturales. La falta de un entorno lingüístico, programas educativos y materiales didácticos fundamentados científicamente, la violación de los fundamentos psicológicos que contribuyen a la preservación de un grupo étnico son las principales bases de la relevancia del estudio. El artículo presenta los resultados de un experimento educativo a largo plazo sobre la preservación de la lengua y la cultura Yukaghir en la escuela secundaria Nelemnoye del distrito Verkhnekolymsky de la República de Sakha (Yakutia), la gestión exitosa del proceso educativo en las nuevas condiciones, su progresiva expansión, desarrollo y creación de un espacio socioeducativo para preservar la lengua y cultura nativas en la aldea Yukaghir. Los resultados prácticos del experimento se pueden utilizar para resolver problemas similares en la sociedad educativa mundial.

Palabra clave: Yukaghirs; Escuela Nacional; Idioma Yukaghir; Cultura Tradicional; Trabajo Educativo.

\section{Introduction}

The system of education and training of the peoples of the North that took shape in the Soviet Union contributed to the disruption of the continuity of generations, the separation of children from the traditional occupations of their parents, the loss of the language and culture of their native people. As the famous scientist N.B. Vakhtin said, "many children left their camp or village, their family and linguistic environment forever, to never return, either literally or linguistically" (Vakhtin, 2004). By the end of the 70s, there was a need to change the situation: the majority of Yukaghir children refused to continue their education, remaining with the received primary education, respectively, only a few received secondary vocational and higher education, thereby creating an acute shortage of personnel in all specialties. In this regard, in 1979, a school in Nelemnoye village was converted to a basic eight-year, and in 1988 - to a complete secondary.

The Nelemnoye village, Verkhnekolymskiy district of the Republic of Sakha (Yakutia), is a place of compact residence of forest Yukaghirs (183 people), where you can still hear the 
language and find traces of the ethnic culture of the Oduls. Five of the forest Yukaghirs are native speakers (there are no native speakers left in Nelemnoye), 17 people speak the spoken language (including 6 people in Nelemnoye), the basics of the Yukaghir language have been studied since 1993 by about 100 graduates of the Tekki Odulok Nelemnoye secondary school (Shadrin, 2014). Thus, to one degree or another, a little more than 120 people speak the Yukaghir language. These facts prompted the International Conference "Languages, Culture and the Future of the Peoples of the Arctic" (Yakutsk, June 1993) to adopt a resolution with a petition to the UN to give the Yukaghirs the status of "disappearing ethnos of the world", and their language - "a disappearing unique language of the world" preserved in Republic of Sakha (Yakutia) (Kurilov, 1996).

However, this did not solve the problem of ethnic identity. Most of the Yukaghirs grew up as Russified marginals, who had lost their native language, culture, connection with nature, who did not adapt to the new conditions of life, which were in constant conflict between the realities of life and the traditional worldview. In the late 1980s, the social situation developed in such a way that most of the children refused to recognize themselves as Yukaghirs: some were ashamed because there was an opinion that the Yukaghirs were second-rate, to whom the labels of "alcoholics" and "parasites" were firmly attached, others because of ignorance of the language, and still others simply did not know about their belonging to the people (Shadrin, 2014).

\section{Material and Methods}

The problem of traditional societies and cultures in the light of their transition to modern societies and cultures, the problem of modernization attracts particular attention of researchers (Chilkote, 2014; Jacobsen, 2015). The works of these researchers accumulated theoretical experience in analyzing the transition from traditional to an industrial society, and general patterns associated with the specifics of societies and cultures undergoing modernization are revealed.

As the researchers note, multicultural education, and, therefore, multicultural educational space opens up great opportunities for learners to master human and national values, for constructive interaction of various ethnic cultures in a multi-ethnic environment, while ensuring a dialogue of cultures (Banks, 2013; Jackson, 2013). Of interest for this study are also ideas that consider the ethnic aspects of the modern cultural process, which have received wide coverage in the scientific literature. In particular, the work of researchers is devoted to the study of the characteristics of ethnic cultures and their interaction (Kane \& Jacobs, 2015).

The problems of preserving cultural diversity today acquire a special meaning and scale, go beyond the framework of local humanitarian problems. When considering the problems of education of indigenous peoples, much attention is paid to the development of national schools (Banks, 1995, Grant, Sleeter, 2000).

The real spiritual life of Yakutia really follows an eclectic path and can be specifically described as "not quite traditional, but also not quite Western," "half traditional and half Western," "both traditional and Western at the same time," etc. This proves that the presence of a national tradition in the life of society is inevitable, especially in the upbringing of the younger generation based on ethnopedagogical aspects of the ethnos (Barakhsanov, Barakhsanova, Golokova, Kronnikov, 2017). The essence of modernization is its compliance with the development trends of the modern world, but the successful movement of modernization is not only in overcoming obstacles from tradition but also in the constructive use of traditional forms as additional incentives for renewal (Barakhsanova, Varlamova, Vlasova, Nikitina, Prokopiev, Myreeva, 2018; Vlasova, Goncharova, Aksyutin, Barakhsanova, Prokopyev, Kuzin, 2018).

The development of national education among the Yukaghirs is relevant due to the critical ethnic situation among these indigenous small people of the North of Russia. A century ago, the 
well-known scholar of northern sciences V.I. Jochelson spoke of the need to take prompt measures to save the Yukaghirs (Jochelson, 2005) and the first scientist from among the peoples of the North, the founder of Yukaghir literature N.I. Spiridonov - Tekki Odulok (Spiridonov, 1996). The first question about the opening of the Yukaghir national school in the late 1980s was raised by the Yukaghir scholar, philologist, poet, and public figure G.N. Kurilov - Uluro Ado, who also developed the concept for the development of the Yukaghir school (Kurilov, 1987). In the early 1990s, the Concept of the National School in the Republic of Sakha (Yakutia) was developed, which became the normative basis for the opening of the Yukaghir national school (Zhirkov, 1992). The formation and development of experimental work in the Nelemnoye secondary school was reflected in the speeches and articles by P.E. Prokopieva (Prokopieva, 2007) and Shadrin V.I. (Shadrin, 2003), certain aspects of the organization of educational and extracurricular activities were presented in articles of the special issue of the journal "Public Education" in 2005 (Ayanitova E.A., Dzingalevskaya T.P., Prokopiev G.G., Prokopieva A.E., Cheprasova E.I., Shalugin A.A.) and many speeches and articles of school teachers Dyachkova E.I., Mironova A.N., Prokopiev G.G., Prokopieva A.E.

One of the first to realize the situation in which the Yukaghirs found themselves, the threat of extinction of culture and loss of language, was realized by the outstanding son of his people, Doctor of Philology Gavril Nikolaevich Kurilov - Uluro Ado. He raised the question of starting the teaching of the Yukaghir language in the schools of the villages of Nelemnoye and Andryushkino, places of compact residence of the forest Yukaghir. The teacher Spiridonov V.K. in collaboration with Nikolaeva I.A. compiled a primer for teaching the native Yukaghir language to children of the forest Yukaghirs (Nikolaeva, Spiridonov, 1993).

In the late 1980s, the rise of the national self-consciousness of the peoples of the USSR began. The need for a special approach to determining the content and forms of education in the schools of the indigenous peoples of the North was declared among the leading ideas and provisions of the Concept of the national school of Yakutia, developed in 1989-1990 led by the Minister of Education of the Republic E.P. Zhirkov (1993). To implement this requirement, curricula were revised in indigenous schools, programs on the mother tongue, national culture; traditional crafts were developed and introduced, depending on the characteristics of each particular school. These transformations also affected the schools of the indigenous peoples of the North, including the Yukaghirs. Ulyana Alekseevna Vinokurova, Doctor of Sociology, became the scientific advisor and author of the concept of the Yukaghir national school.

In her opinion, "the survival, preservation, and revival of a nationally distinctive culture and way of life are possible only if a multivariate model of upbringing and education of children of the peoples of the North is created". One of the fundamental principles of the Concept of upbringing and education of children of the peoples of the North, proposed by her, proclaimed "...a complex of upbringing and educational process on the formation of a child's personality precisely as a representative of a particular people of the North. To do this, he must assimilate the appropriate spiritual culture of his native people, go through the cold hardening system, profess the moral and ethical norms of northern morality, become a carrier of national identity, know the history of this ethnic group and, as he grows up, take responsibility for its fate" (Vinokurova, 1997).

The main task of the experiment was the introduction of folk traditions into the education system, the study and preservation of the language and culture of the small northern people - the forest Yukaghirs. During the experiment, the curriculum of the Yukaghir national school was developed and tested, which included new academic disciplines: "Yukaghir language" (by V.K. Spiridonov), "National culture" (by EI Dyachkova), "Literature of indigenous peoples North" (by Naumova D.I., Dzingalevskaya T.P., and Cheprasova E.I.), "Yukaghir craftswoman" (by Dyachkova E.I.), "Hunting and hunting trades" (by Prokopiev G.G.), "Local history" (by Bushkov Yu.T.), "Lessons of folklore" (by Dyachkova I.A.) (Dzingalevskaya, 2015, Dyachkova, 2004a, 2015b). 
Elements of the Yukaghir language and national culture have been introduced into the subjects of the federal cycle to create and expand the linguistic and cultural-educational space (biology in grades 5-9, mathematics in grades 5-9, art in grades 1-6, physical education in grades 1-11) (Ayanitova, 2005, Shalugin, 2005). The elective courses were introduced: "Geography of our land" in grade 8 (Gabysheva E.D.), "School of physical training" Kichil" in grades 8-11 (Cheprasov M.Yu.), "Ecology of sable in the Kolyma river basin" in grade 8" (Cheprasov M.Yu.), "Geography" in grades 6-9 (Gabysheva E.D.).

In 1994, the school received the status of national, and in 1995 it was recognized as one of the eight basic schools of the indigenous peoples of the North of the Republic of Sakha (Yakutia). In 1996, the Nelemnoye secondary school was named after the founder of Yukaghir literature, the first scientist from the northerners, Nikolai Ivanovich Spiridonov (Teki Odulok).

In the course of the experiment, obvious problems characteristic of the small northern peoples appeared: the lack of proper support for the work of the school from the family and rural society, low motivation for development, pessimism in terms of views on the future of their people and children. Therefore, after the creation of an appropriate cultural and educational environment at school, the introduction of a basic curriculum with the introduction of the Yukaghir culture and knowledge of the language, literature, culture, traditions into the current schedule of educational and educational work, the goal was to integrate the educational process with the activities of rural society and create a single system - the ethnocultural center of the Nelemnoye village based on the Nelemnoye secondary school named after Tekki Odulok. This project was submitted to the Ministry of Education of the Republic of Sakha (Yakutia) and defended in December 2000 (scientific supervisor P.E. Prokopieva. To achieve this goal, the following tasks were set:

- Development and implementation of programs for studying and promoting the language and culture of the Yukaghir people in kindergarten, school, rural community center as a single complex;

- Development and implementation of programs for spiritual, moral and legal education, valeologization of education, promotion, and implementation of a healthy lifestyle with the participation of the family and rural society;

- Involvement of the local administration, the community center, the local hospital, the public in the creation of an appropriate cultural and educational environment;

- Development of a program and preparation of a base for vocational training for high school students and young people under the programs "Farmer of the Northern Economy" and "Master of Fur Clothing" for girls in cooperation with the Yukaghir community "Tekki Odulok" and the peasant farms of the village;

- Creation of a school audio-visual fund with audio, photo, video and printed materials with samples of live speech, folklore, and culture of the Yukaghir people;

- Deepening and expanding work on the socialization of the individual through the further improvement of career guidance work, the formation of traditional life support skills.

One of the main forms of enhancing the educational activity of students has become research work on the literature of the indigenous peoples of the North, national culture, and history of the native land, the results of which are regularly presented at ulus and republican school conferences.

\section{Results}

The organization of educational work was supplemented with the new forms of organization of extracurricular work - well-known elements of the cultural traditions of the Yukaghir people. It has become traditional to hold a month of national culture, within which ethnocultural holidays 
"Hangiche" ("The best hunter"), "Chahadan paipadie" ("Girl from Yasachnaya") [Regulations, 2010], the scientific and practical conference "Yukaghirs: traditions and modernity", Spartakiad "Games of the Ancestors".

Monthly celebrations dedicated to the anniversaries of famous Yukaghir culture figures became a kind of immersion in the national culture. The school folklore ensemble "Yarkhadana" became more active and became an important part of the experiment. Reconstructions were carried out and many folk rituals and rituals were included in the program of performances, search work is carried out with native speakers of the language and culture, interesting and unique samples of the musical song culture of the people are recorded, which are creatively processed and subsequently presented to the general public (Shadrin, 2003, Mironova, 2018, Prokopyeva, 2008, Cheprasova, 2005).

Following the program, much attention is paid to the labor education of students. Labor practices were implemented through adjustments to the educational calendar: fishing is held in the first 2 weeks of September, and hunting is held in the second week of May. A school section functions annually, the products of which are sent to the school canteen. Since 2002, a summer ecological and linguistic camp of work and rest for high school students "Mat Labie" was organized, during which students traveled to the historical places of the Yukaghirs, collected materials on the history and culture of their native land, applied knowledge of traditional crafts in practice. Every summer, a playground is organized at the school, the children take an active part in the improvement of their village. It is also important that the school helps high school students to find a job in summer. Such a long period of the experiment was provided by the correct planning of work and constant monitoring of activities, timely control, and tracking of the results of experimental activities.

Therefore, in the initial period of the experiment, special attention was paid to the psychodiagnostic of students. In the senior grades, vocational guidance studies were regularly conducted, according to the results of which students were provided with special elective courses and electives. Thus, the children had the opportunity of individual professional self-determination with the help of teachers and constant consultations of a psychologist.

Continuous monitoring was based on the constant analysis of data from weekly workshops with a discussion of the results of the work done, on the progress of the educational process on experimental curricula, as well as submitted to the Pedagogical Council based on academic quarters at the end of each quarter of written reports with self-analysis. In this way, the reasons for various difficulties were identified, the progress of children was analyzed, and in practice, methods of solution and correction were determined. Because of ensuring constant management and analysis of pedagogical actions, there was never a decrease in the basic level of training following the Federal State Educational Standard, moreover, in some courses; there was an increase in indicators. The Yukaghir language has become an integral component of all school activities. The translation of the scripts was mainly carried out by the teachers of the Yukaghir language and the participants of the "Translator" elective course. Every year, together with parents and students, the school develops various programs for extracurricular activities with a national focus: circles "Orpundyaraa", "Yarkhadana", "Yakhte", "Translator", optional classes "Labor training and hunting trades", "Yukaghir craftswoman" - "Indianuy paipadie", "Local history", elective courses of "School of survival "Kichil", "Ecology of the sable in the Kolyma river basin" (Mironova, 2019, Prokopieva, 2005).

For schoolchildren, it has become traditional to hold competitions "Haniche" (Best Hunter) and "Chahadan Paipaadie" (The Girl from Yasachnaya). Initially, they were conceived as forms of forming students' interest in their native culture, but now they have resulted in constant competition. 
In 2007, the school became involved in the implementation of the UNESCO project "Promotion of the preservation of the Yukaghir language and traditions by strengthening the resources of educational institutions in places of compact residence in the Republic of Sakha (Yakutia)". Within the framework of the project, digital equipment was purchased for collecting linguistic, folklore and ethnographic materials (voice recorder, video camera), master classes of native speakers of the Yukaghir language and traditions, works of folklore were recorded on digital media (about 8 hours of video, 4 hours of audio materials). The activities carried out under the UNESCO project allowed for the first time to involve schoolchildren in the collection and decoding of folklore materials, to give the process of teaching their native language a personal character through direct communication between students and the Yukagir culture carriers.

The ethnocultural center is currently actively cooperating with various institutions and organizations of the republic: an experiment has been started in a kindergarten under the direction of the Research Institute of National Schools of the Republic of Sakha (Yakutia) "Yukaghir language for preschoolers", cooperation has been established with the Institute of Humanitarian Research and Problems of Indigenous Peoples of the North of the Siberian Branch of the Russian Academy of Sciences, Institute of National Schools of the Republic of Sakha (Yakutia) in the development of teaching aids, together with the Museum of Music and Folklore of the Peoples of Yakutia, prepared and released discs of the series "Folklore of the Yukaghirs of the Upper Kolyma" (currently there are 7), together with the Association of Yukaghirs and the Council of Elders of the Yukaghir and teaching aids published.

Regular questionnaires of students, parents, the village community on the most important areas of the ethnocultural center's work, based on the results of which the activities of the experiment participants are analyzed and corrected, shows the great interest of the population in further work in this direction, a large number of various comments and suggestions are received from the villagers. The authors made sure that the population is in demand for knowledge of the history, national culture of the Yukaghir people, and the study of traditional crafts. There are more and more opinions about the need for active work by the administration of the village and the rural house of culture in the activities of the school.

A local history museum has been created and is actively functioning at the school, where unique exhibits on the material culture of the people, collected and created during the experiment, are exhibited. The results of the search and research activities of the school museum and the school library, together with the rural library, the house of culture, are demonstrated at exhibitions and interesting events on the history, literature, and culture of the Yukaghirs. Various institutions and organizations of the village take part in organizing events on the history and literature of the Yukaghirs, so we can assert that the population actively and willingly participates in their native culture. Courses are held for those wishing to speak Yukaghir with the maximum involvement of materials from the school museum, a laboratory room on the Yukaghir national culture, master classes given by the oldest native speakers of the language and culture of the Yukaghir people.

One of the practical results of the work of the school teachers and all the experimental work was the release of textbooks for studying the Yukaghir language and culture Songs and oral genres of the folklore of the Yukaghir people are recorded and translated into digital media. The School Fund collected more than 100 audio and video materials, CD recordings of unique samples of "live" speech, folklore, and culture of the Yukaghir people. The Fund is replenished mainly due to the materials of researchers and expedition participants. The issues of the school newspaper "Odun losilpe" have become traditional, some of the materials of which are published in the Yukaghir language. 


\section{Discussion}

School events always attract the attention of the entire population of the village. Therefore, in the educational plan of the school, events appeared at which it would be possible and appropriate to attract materials on the Yukaghir language, folklore, and culture. Such events were folklore evenings, Day of the Elderly, Mother Language Day, Mother's Day, etc.

The school set itself the task of reconstruction based on ethnographic materials and the holding of folk holidays in the village - the Feast of the First Hunt, Unun-Pogil (Worship of the Spirit of Water). However, this work is complicated by such factors as the small amount of preserved materials, insufficient training of teachers for the restoration of cultural and ethnographic phenomena.

In the direction of "Kindergarten - school" classes are held in the Yukaghir language. Classes in the Yukaghir language for kindergarten are taught by school teachers according to the teaching manual "Yukaghir (Odul) language for preschoolers" by Prokopieva P.E., the Candidate of Pedagogy, which was published in 2005. The content of the teaching material of the manual is developed taking into account the possibility of a teacher's creative search, which allows him to consciously and creatively approach the learning process, adjust the program and make own efforts for a successful result (Prokopieva, 2005). Programs of new ethnocultural contests for children of preschool and primary school age "Kuopeduo Ileie - The Boy of Brezze", "Paipeduo Yeloodye - The Girl of the Sun" have been formed.

One of the practical results of the work of the school teachers and all the experimental work was the release of textbooks for the study of the Yukaghir language and culture. Songs and oral genres of the folklore of the Yukaghir people are recorded and translated into digital media. The School Fund collected more than 100 audio and video materials, CD recordings of unique samples of "live" speech, folklore, and culture of the Yukaghir people. The Fund is replenished mainly due to the materials of researchers and expedition participants. The issues of the school newspaper "Odun losilpe" have become traditional, some of the materials of which are published in the Yukaghir language.

\section{Conclusion}

Thus, the Nelemnoye secondary school is a vivid example of active planned work to preserve the Yukaghir language and culture. The experimental work of the school took place in difficult conditions of the absence of a linguistic environment when children did not know their native language and could only learn it at the school. Currently, educational and methodological literature has been created on teaching the native language, teaching native literature, national culture, active assistance to the work of the school from the family, and rural society has been organized.

The main content of experimental activities in the Nelemnoye secondary school named after Tekki Odulok made up the development of an educational program and practical testing of curricula, the introduction of various forms of educational and extracurricular work (events focused on the transfer of knowledge about the language, traditional culture, circles and electives of language and ethnocultural orientation, etc.). This became the basis for expanding the social orientation of the experiment and served as the basis for its durability and effectiveness. Experimental work at the school resulted in museums, folklore ensembles, social involvement, development, and publication of teaching aids.

Successful management of the work of the school under the conditions of the experiment led to the intensification of the educational activities of students, the rise of interest in their native culture, research work, the implementation of mental and creative principles through the 
development of new forms of organization of extracurricular work, the integration of the activities of the school and rural society.

Scientific support of experimental processes was provided through cooperation with the Institute of Problems of Indigenous Peoples of the North of the Siberian Branch of the Russian Academy of Sciences, Institute of National Schools of the Republic of Sakha (Yakutia), Ammosov North-Eastern Federal University, the Museum of Music and Folklore of the Peoples of Yakutia. Cooperation is underway with public organizations - the Yukaghir Association and the Council of Elders of the Yukaghir people.

Now the whole world is building a School of cooperation, co-creation, co-development, the main goal of which should be a Personality who is confident in the future, who owns not only digital technologies that master us at cosmic speed, but who has humanitarian competencies, who knows how to live and develop in a team, in society ready for self-development. And the remote small Nelemnoye school, which set as its goal the preservation of its people, realizes these competencies in its students easily and progressively. The most important thing that the school has achieved is that the student has become an active participant in a large social human experiment, a co-author of all curricula and manuals, a conductor, propagandizing the knowledge gained and introducing the family to the process of preserving language and culture, to the revival of the people.

\section{References}

Ayanitova, E.A. (2005). Mathematics and the national-regional component. Public education, 1.

Banks, J. A. (2013). The construction and historical development of multicultural education, 1962-2012. Theory into Practice, 52, 73-82.

Banks, J.A. (1995). Multicultural Education: Historical Development, Dimensions, and Practice. In J.A. Banks \& C.A. Banks (eds.). Handbook of Research on Multicultural Education. New York: Macmillan.

Barakhsanov, V.P., Barakhsanova, E.A., Golokova, V.S., Kronnikov, N.D. (2017). Ethniceducational aspects of intellectual games development process in Sakha (Yakutia) Republic. Theory and Practice of Physical Culture, 7, 34.

Barakhsanova, E.A., Varlamova, V.A., Vlasova, E.Z., Nikitina, E.V., Prokopyev, M.S., Myreeva, A.N. (2018). Vocational training of school teachers in Yakutia's universities through the principle of regionalization (a case study of the methodology of teaching natural science to prospective teachers). Espacios, 39(20).

Cheprasova, E.I. (2005). Extracurricular work on the Yukaghir language and literature in the Nelemnoye secondary school named after Tekki Odulok. Public education, 1.

Chilkote, R.H. (2018). Theories of comparative politics. New York: Routledge.

Dyachkova, E.I. (2015a). Yukaghir bonfires - Odun losilpe, grade 1: textbook. Yakutsk: Bichik.

Dyachkova, E.I. (2015b). Yukaghir bonfires - Odun losilpe, grade 2: textbook. Yakutsk: Bichik.

Dzingalevskaya, T.P. (2005). The lessons of the literature of the North in primary school. Public education, 1.

Grant, C.A., Sleeter, C.T. (2000). Turning on Learning/Five Approaches for Multicultural teaching. Plans for Race, Gender, and Disability. John Wiley \& Sons, Inc.

Iokhelson, V.I. (2005). Yukaghirs and Yukaghirized Tunguses. Novosibirsk: Nauka.

Jackson, L (2015). Revisiting the Modernization Hypothesis: Longevity and Democracy. World Development, 67, 174-185.

Jackson, L. (2013). Multicultural or intercultural education in Hong Kong? International Journal of Comparative Education and Development, 15(2), 99-111.

Kane, M. \& Jacobs, R. (2015). Beliefs about safety and religious and cultural diversity. Journal of Social Service Research, 41(5), 622-641. 
Kurilov, G.N. (1996). Revival of the culture and language of the Yukaghirs. Problems of the revival of the disappearing Yukaghirs. Yakutsk: Northern Studies.

Kurilov, G.N. (1996). Revival of the culture and language of the Yukaghirs. Problems of the revival of the disappearing Yukaghirs. Yakutsk: Northern Studies.

Mironova, A.N. (2019). The work of Municipal state-owned educational institution "Nelemnoye secondary school named after N.I. Spiridonov - Tekki Odulok" on the preservation of the endangered language and traditional culture of the Yukaghirs. Retrieved from: https://nsportal.ru/shkola/raznoe/library/2019/04/04/rabota-mkou-nelemninskaya-soshim-n-i-spiridonova-tekki-oduloka-po

Mironova, A.N. (2020). Organization of extracurricular activities in the Yukaghir language at Municipal state-owned educational institution "Nelemnoye secondary school named after N.I. Spiridonov and Tekki Odulok". Retrieved from: https://nsportal.ru/shkola/inostrannye-yazyki/drugieyazyki/library2018/01/13/organizatsiya-vneurochnoy-deyatelnosti-po

Prokopiev, G.G. (2005). Haniche means the best hunter. Public education, 1.

Prokopieva, P.E. (2008). Nelemnoye secondary school is a republican experimental site. Kolyma news.

Prokopyeva, P.E. (2007). Yukaghir school: problems and development prospects. Problems of the native language in the context of globalization and integration of modern society: Collection of scientific articles. Yakutsk: IGI AN RS(Y).

Shadrin, V.I. (2003). School is an ethnocultural center for the revival of the people. Seminar on the implementation of UNESCO recommendations (1989) on the preservation of traditional culture and folklore in the Siberian region of the Russian Federation, 1922.08.2001: Collection of the exhibition's participants. Yakutsk.

Shadrin, V.I. (2003). School is an ethnocultural center for the revival of the people. Seminar on the implementation of UNESCO recommendations (1989) on the preservation of traditional culture and folklore in the Siberian region of the Russian Federation, 1922.08.2001: Collection of the exhibition's participants. Yakutsk.

Shadrin, V.I. (2014). Transformation of Yukaghir ethnic identity in modern conditions. Humanities and social sciences, 1.

Spiridonov, N.I. (1996). The Odul people (Yukaghirs) of the Kolyma district. Yakutsk: Severoved.

Vinokurova, U.A. (1997). Upbringing and education of children of the peoples of the North. Yakutsk.

Vlasova, E.Z., Goncharova, S., Aksyutin, P., Barakhsanova, E.A., Prokopyev, M.S., Kuzin, Z. (2018). Effective adaptive training of students in Russian pedagogical universities to use e-learning technologies. Espacios, 39(23).

Zhirkov, E.P. (1992). How to revive a national school. Steps of the Republic of Sakha (Yakutia): Articles and materials. Moscow: Education.

Zhirkov, E.P. (1993). Education and Development: A National Strategy on the Approaches to the 21st Century. National school: concept and technology of development. Moscow: Education. 